PALEOCEANOGRAPHY, VOL. 4, No. 6, PAGES 681-691, DECEMBER 1989

\section{LITHIUM-TO-CALCIUM RATIOS IN MODERN, CENOZOIC, AND PALEOZOIC ARTICULATE BRACHIOPOD SHELLS}

M. L. Delaney

Institute of Marine Sciences, University of California, Santa Cruz

\section{B. N. Popp}

Biogeochemical Laboratories, Departments of Chemistry and Geology, Indiana University, Bloomington

C. G. Lepzelter and T. F. Anderson

Department of Geology, University of Illinois, Urbana

Abstract. Li/Ca ratios in modern brachiopod shells generally correlate inversely with growth temperature, ranging from $\sim 20 \mu \mathrm{mol} / \mathrm{mol}$ at $30^{\circ} \mathrm{C}$ to $\sim 50 \mu \mathrm{mol} / \mathrm{mol}$ at $0^{\circ} \mathrm{C}$ with no apparent interspecific offsets. Causes of the temperature effect on Li/Ca ratios are not yet understood. Cenozoic brachiopod Li/Ca ratios average $-30 \mu \mathrm{mol} / \mathrm{mol}$, similar to the average observed in modern brachiopods. Relatively constant $\mathrm{Li} / \mathrm{Ca}$ ratios for Eocene to Pleistocene nonluminescent brachiopod shells, consistent with previous observations of Cenozoic planktonic foraminifera, support the conclusion of little variation in Cenozoic seawater $\mathrm{Li} / \mathrm{Ca}$. Nonluminescent portions of Permian and Carboniferous brachiopods have $\mathrm{Li} / \mathrm{Ca}$ ratios substantially lower (generally $<10$ $\mu$ mol/mo1) than modern, Cenozoic, or Devonian samples. Mass balance considerations, constrained by $\delta^{18} 0$ of brachiopods, suggest that low Li concentrations in Permo-Carboniferous seawater could be the result of a lower flux of dissolved $\mathrm{Li}$ from the continents and/or a higher flux of Li from seawater to clastic marine sediments. Nonluminescent Devonian brachiopods from a single hand specimen

Copyright 1989

by the American Geophysical Union.

Paper number 89PA01692.

$0883-8305 / 89 / 89$ PA-01692\$10.00 have $\mathrm{Li} / \mathrm{Ca}$ ratios around $70 \%$ of the modern average. These $\mathrm{Li} / \mathrm{Ca}$ ratios can be explained by either somewhat higher temperature with constant seawater $\mathrm{Li} / \mathrm{Ca}$, somewhat lower seawater $\mathrm{Li} / \mathrm{Ca}$ at constant temperature, or a combination of slightly elevated temperature and slightly lower seawater $\mathrm{Li} / \mathrm{Ca}$.

\section{INTRODUCTION}

The geochemical cycle of lithium makes its seawater concentration a potential monitor of chemical fluxes from axial hydrothermal circulation through time. Li is supplied to the oceans from rivers and from high-temperature hydrothermal circulation at ridge crests; it is removed from the oceans by incorporation in marine sediments enriched in $\mathrm{Li}$ relative to continental precursors and by low-temperature basalt alteration [Holland, 1978, p. 200, 1984, pp. 209-227; Edmond et a1., 1979; Stoffyn-Egli and Mackenzie, 1984; Von Damm et al., 1985; Chan and Edrnond, 1988]. Li is essentially conservative in seawater, with no significant involvement in biological activity or scavenging by particles [Stoffyn-Egli and Mackenzie, 1984]. Quantitative estimates of global fluxes are not well constrained, but hydrothermal input of $\mathrm{Li}$ is at least equal to the river flux at present and may be as much as a factor of 10 greater. Residence time is of the order of $\leq 1 \mathrm{~m} . \mathrm{y}$. [Edmond et al., 1979; Stoffyn-Egli and Mackenzie, 1984]. 
Because marine sediments are enriched in Li relative to continental precursors, oceanic crust must be a net contributor of dissolved Li to the oceanic pool. In other words, for marine sediments to be enriched in Li under steady state conditions, low-temperature basalt alteration must be a smaller proportion of the total removal flux than high-temperature alteration is of the total input flux. Low-magnesium calcite shells of foraminifera grown in laboratory culture experiments are good indicators of seawater lithium-to-calcium ratios [Delaney et al., 1985]. Over the past $100 \mathrm{m.y}$., mean $\mathrm{Li} / \mathrm{Ca}$ for mixed planktonic foraminiferal shells averaged in age intervals of 5-10 m.y. was no more than 168 greater or 258 less than the mean $\mathrm{Li} / \mathrm{Ca}$ ratio of all samples [Delaney and Boyle, 1986]. Interpretation of these data using a mass balance model for Li constrained hydrothermal fluxes to have been no more than $30-408$ greater than those at present for intervals any longer than one million years during this time.

We report here the first analyses of Li/Ca ratios in well-preserved portions of modern, Cenozoic, and Paleozoic articulate brachiopod shefls in an effort to extend the $\mathrm{Li} / \mathrm{Ca}$ record into the Paleozoic. Low-magnesium calcite shells of articulate brachiopods have yielded records of oceanic oxygen, carbon, and strontium isotopes [e.g., Lowenstam, 1961; Popp et al., 1986a, c; Veizer et al., 1986]. Their minor element contents have not yet been utilized fully as records of oceanic chemical composition, but have been interpreted as indicators of diagenetic alteration [e.g., Brand and Veizer, 1980].

\section{SAMPLES}

Modern, Cenozoic, Permo-Carboniferous, and Devonian brachiopod samples were analyzed in this study (Tables 1-4). The modern brachiopods, a11 of the superfamily Terebratulidae, were obtained mainly from the collections at the American Museum of Natural History [Lepzelter et al., 1983]. Cenozolc samples as well as a few modern samples (all of the superfamily Terebratulidae) were from the brachiopod collections of the Museum of Natural History, Smithsonian Institution. The Permo-Carbonfferous samples, including both Productidinae and Spiriferidae, had been analyzed in earlier studies of $\delta^{18} 0$. $\delta^{13} \mathrm{C}$, and ${ }^{87} \mathrm{Sr} /{ }^{86} \mathrm{Sr}$ [Popp et al., 1986a, c]. The Middle Devonian Spiriferidae samples were new samples collected from the Hungry Hollow Formation, Ontario, which was described, sampled, and analyzed by Popp et al. [1986b].

Sample powders were obtained using microsampling techniques from the nonluminescent portions of the brachiopod shells, typically the hinge area, inferred by Popp et a1. [1986a, b, c] to be best preserved as deduced from textural, trace element, and stable isotope results. Some modern samples were taken from carefully cleaned pieces of shells. For the middle Devonian and some Cenozoic and late Paleozoic samples, calcareous matrices surrounding the fossil shells and sparry cements associated with the shells were also sampled; their compositions provide information on diagenetic trends.

\section{METHODS}

A summary of methods is given here; a more complete description of methods is available on request to the authors. Brachiopod samples as powders were dissolved in $0.5 \mathrm{~N}$ (redistilled) nitric acid. Li concentrations in brachiopod shell. material, reported as $\mathrm{Li} / \mathrm{Ca}$ mole ratios, were analyzed by graphite furnace atomic absorption spectrophotometry (GFAAS) using methods developed for foraminiferal shells (see Delaney [1983] for details). Li was analyzed by GFAAS using duplicate $20 \mu 1$ injections at the recommended conditions with a Perkin-Elmer 5000 atomic absorption spectrophotometer, a Perkin-Elmer HeatedGraphite-Analyzer 500, and a Perkin-Elmer AS-1 autosampler. Background correction with a tungsten halide continuum source was used for all $\mathrm{Li}$ analyses. Reagent and instrumental Li blanks were minor compared to sample concentrations. Sample Li/Ca ratios were typically greater than 5 times the detection limit (defined as 3 times the standard deviation of multiple measurements of a blank), and generally exceeded the detection limit by much higher factors.

$\mathrm{Ca}$ concentrations were determined adding lanthanum as an ionization suppressant. These flame atomf absorption analyses were carried out on a PerkinElmer 2380 spectrophotometer using a single-slot burner with an air-acetylene flame. Sr, Mg, Mn, and Fe results for most of the modern samples are from Lepzelter et al. [1983] and for the PermoCarboniferous samples are from Popp et al. [1986a]. For all other samples, $\mathrm{Sr}$ was 
TABLE 1. Modem Brachiopods

\begin{tabular}{|c|c|c|c|c|c|c|c|c|c|c|}
\hline Sample & Identification & Locality & $\begin{array}{c}\text { Depth, } \\
\text { m }\end{array}$ & $\begin{array}{c}\mathrm{T},{ }^{\mathrm{C}} \mathrm{C} \\
\text { (Estimated } \\
\text { Mean Annual) }\end{array}$ & $S$ & $\begin{array}{c}\mathrm{Li} / \mathrm{Ca} \\
\mu \mathrm{mol} / \\
\mathrm{mol} \\
\end{array}$ & $\begin{array}{c}\mathrm{Sr} / \mathrm{Ca} \\
\mathrm{mmol} \\
\mathrm{mol}\end{array}$ & $\begin{array}{c}\mathrm{Mg} / \mathrm{Ca} \\
\mathrm{mmol} / \\
\mathrm{mol}\end{array}$ & $\begin{array}{c}\mathrm{MnCa} \\
\mathrm{Hmol} \\
\mathrm{mol}\end{array}$ & $\begin{array}{c}\mathrm{FeCa} \\
\mathrm{mmol} \\
\mathrm{mol} \\
\end{array}$ \\
\hline RBT & Thecidellina baretti & Jamaica & 20 & $27.4 \pm 1.3$ & 36.1 & 20.1 & 2.45 & 10.0 & 36 & 0.25 \\
\hline RBL & Lacazella carib. & Jamaica & 10 & $27.5 \pm 1.3$ & 36.1 & 17.7 & & & & \\
\hline CBCA (1) & Argyotheca johnsoni & Belize & 30 & $27.5 \pm 0.7$ & 36.2 & 23.6 & & & & \\
\hline CBCA (2) & Argyotheca johnsoni & Belize & 30 & $27.5 \pm 0.7$ & 36.2 & 21.0 & & & & \\
\hline CM1 & Tichosina floridensis & Dry Tortugas & 180 & $18.4 \pm 1.5$ & 36.2 & 5.7 & 0.95 & 9.7 & 27 & 0.18 \\
\hline CM7 & Laqueus californicus & California & 55 & $11.1 \pm 4.0$ & 33.4 & 38.9 & 1.04 & 5.8 & 36 & 0.16 \\
\hline R3 & Laqueus vancouveriensis & Juan de Fuca St. & 225 & $7 \pm 4$ & 33 & 36.6 & 1.34 & 8.1 & 148 & 2.33 \\
\hline $\mathrm{R} 4$ & Neothyris lenticularis & Antipodes Island & 100 & $8 \pm 2$ & 34.2 & 37.4 & 1.58 & 25.1 & 32 & 0.63 \\
\hline CDIP6 & Terebratulina septention. & Bay of Fundy ${ }^{b}$ & 20 & $7.1 \pm 6.4$ & 32.1 & 41.2 & 1.15 & 11.9 & 64 & 0.20 \\
\hline CDIP7 & Terebratulina septention. & Bay of Fundy & 20 & $7.1 \pm 6.4$ & 32.1 & 40.6 & & & & \\
\hline MF22 & Terebratulina uniquicula & Puget Sound & 130 & $7.4 \pm 2.5$ & 33.6 & 37.2 & 1.25 & 13.0 & 27 & 0.25 \\
\hline MF3 & Hemitayris psittacea & Puget Sound & 130 & $7.4 \pm 2.5$ & 33.6 & 40.2 & & & & \\
\hline SM6 & Hemitayris psittacea & Bering Sea AK & shallow & $3 \pm 5$ & 33.5 & 49.2 & 1.41 & 5.0 & 27 & 0.18 \\
\hline $\mathrm{R} 1$ & Magellania maquariensis & South Pacific & 120 & $7.0 \pm 0.5$ & 34.1 & 38.9 & 1.24 & 9.5 & 76 & 0.55 \\
\hline
\end{tabular}

Most minor element data are from Lepzelter et al. [1983]; data for R1-4 are from this study.

${ }^{a}$ Estimates were based on existing oceanographic data on water masses at same depths from locations as close to collection sites as possible.

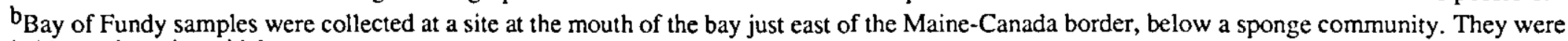
probably not in an intertidal zone.

TABLE 2. Cenozoic Brachiopods

\begin{tabular}{|c|c|c|c|c|c|c|c|c|c|c|}
\hline Sample & Identification & Locality & Age & $\delta^{13} \mathrm{C}$ & $\delta^{18} \mathrm{O}$ & $\begin{array}{c}\mathrm{Li} / \mathrm{Ca} \\
\mu \mathrm{mol} / \\
\mathrm{mol}\end{array}$ & $\begin{array}{c}\mathrm{Sr} / \mathrm{Ca} \\
\mathrm{mmol} / \\
\mathrm{mol}\end{array}$ & $\begin{array}{c}\mathrm{Mg} / \mathrm{Ca} \\
\mathrm{mmol} / \\
\mathrm{mol}\end{array}$ & $\begin{array}{c}\mathrm{Mn} / \mathrm{Ca} \\
\mu \mathrm{mol} / \\
\mathrm{mol}\end{array}$ & $\begin{array}{c}\mathrm{Fe} / \mathrm{Ca} \\
\mathrm{mmol} \\
\mathrm{mol}\end{array}$ \\
\hline$\overline{\mathrm{C}-2}$ & Neothyris sp. & New Zealand & Pleistocene (Hawtowan) & 2.12 & 2.35 & 24.5 & 1.07 & 3.1 & 12 & 0.49 \\
\hline C-3 & Muhlfeldtia sp. & Greece & Pleistocene & 2.58 & 3.46 & 34.2 & 1.18 & 18.0 & 51 & 0.55 \\
\hline C-4 & Dallinella sp. & California & Pliocene & 1.10 & 0.74 & 30.7 & 1.12 & 5.4 & 5 & 0.18 \\
\hline C-12 & Dallinella occidentalis & Califomia & Middle Pliocene & 1.09 & 0.70 & 29.0 & 0.99 & 6.5 & 12 & 0.16 \\
\hline C-10 & Laqueus sp. & Califomia & Middle Pliocene & 0.80 & 0.32 & 35.1 & 1.09 & 6.8 & 18 & 1.31 \\
\hline C-5 & Muhlfeldtia truncata & Sicily & Pliocene & 1.57 & 2.28 & 30.7 & 1.21 & 16.3 & 56 & 0.20 \\
\hline C-8 & Dallinnella sp. & Califomia & Late Miocene & 0.94 & -0.10 & 31.0 & 1.00 & 6.1 & 5 & 0.12 \\
\hline C-7A & Magellania tateana & S. Australia & Miocene (Aldingian) & 2.20 & 0.10 & 29.4 & 0.90 & 5.6 & 35 & 0.14 \\
\hline $\mathrm{C}-7 \mathrm{~B}^{*}$ & Magellania tateana & S. Australia & Miocene (Aldingian) & 1.45 & -0.21 & 31.6 & 0.98 & 6.2 & 135 & 0.33 \\
\hline C-6 & Pachymagas huttoni & New Zealand & Oligocene & 2.85 & 0.93 & 31.0 & 1.04 & 3.3 & 55 & 0.10 \\
\hline C-9 & Pachymagas sp. & New Zealand & Oligocene & 3.12 & 1.14 & 34.1 & 1.01 & 3.9 & 22 & 0.21 \\
\hline C-11 & Terebratula harlani & New Jersey & Eocene & 2.61 & 0.28 & 27.2 & 1.13 & 4.1 & 30 & 1.44 \\
\hline
\end{tabular}

${ }^{*} \mathrm{C} 7 \mathrm{~B}$ oxygen and carbon isotope values indicate matrix contamination by comparison to measured values for $\mathrm{C} 7 \mathrm{~A}$ and their matrix. 
TABLE 3. Permian and Carboniferous Brachiopods

\begin{tabular}{llllr}
\hline Sample & \multicolumn{1}{c}{ Identification } & \multicolumn{1}{c}{ Locality } & \multicolumn{1}{c}{$\begin{array}{c}\text { Li/Ca } \\
\text { Amol/ }\end{array}$} & $\begin{array}{r}\text { Age } \\
\text { mol }\end{array}$ \\
\hline TI-97-NL-1 & Camarophoria purdoni & Timor (Broidi) & Late Permian (Kungurian) & 6.2 \\
TI-83-NL-1 & Martinia sp. & Timor (Kiosuoko) & Late Permian (Kungurian) & 5.4 \\
TI-83-WB* & Martinia sp. & Timor (Kiosuoko) & Late Permian (Kungurian) & 7.7 \\
TI-83-M* & matrix & Timor (Kiosuoko) & Late Permian (Kungurian) & 14.6 \\
YU-9-NL-1 & Martinia sp. & Yugoslavia (Karavanke Mtns) & Early Permian (Sak.-Art.) & 0.5 \\
E324-WB & Choristites sp. & Spain (Prov. Oviedo) & Late Carb. (Kasimovian) & 1.5 \\
E324-M* & matrix & Spain (Prov. Oviedo) & Late Carb. (Kasimovian) & 33.3 \\
E246-NL-1 & Choristites sp. & Spain (Prov. Oviedo) & Late Carb. (M. Moscovian) & 4.2 \\
E132-NL-1 & Choristites sp. & Spain (Prov. Palencia) & Late Carb. (E. Moscovian) & 1.4 \\
E331-NL-1 & Choristites sp. & Spain (Prov. Palencia) & Late Carb. (E. Moscovian) & 1.4 \\
AL5-WB* & Gigantoproductus sp. & Algeria (W. Sahara) & Early Carb. (E. Serpukh.) & 17.6 \\
AL5-BL-3 & Gigantoproductus sp. & Algeria (W. Sahara) & Early Carb. (E. Serpukh.) & 12.1 \\
B14-NL-1 & G. gigantus & Belgium (Royseux) & Early Carb. (L. Visean) & 4.4 \\
B14-M* & matrix & Belgium (Royseux) & Early Carb. (L. Visean) & 3.0 \\
GB236-NL-1 & Gigantoproductus sp. & Great Britain (Scotland) & Early Carb. (L. Visean) & 18.9 \\
GB79-6-NL-1 & Martinia sp. & Great Britain (England) & Early Carb. (L. Visean) & 3.5 \\
\hline
\end{tabular}

Minor element data are given by Popp et al. [1986a].

aSample designations are: NL, nonluminescent portions microsampled; BL, brightly luminescent; WB, whole brachiopods; $\mathrm{M}$, surrounding matrix; *, insoluble residues visible after dissolution.

${ }^{b}$ Abbreviations are Sak.-Art, Sakmarian-Artskian; Carb., Carboniferous; M, E, L, Middle, Early, Late; Serpukh., Serpukhovian.

analyzed by GFAAS on an aliquot of the $\mathrm{Ca}$ solution. Mn was analyzed by GFAAS. Mg (with cesium added as an ionization suppressant) and $\mathrm{Fe}$ were analyzed by small-volume injection using a microsampling cup with flame atomic absorption spectrophotometry at recommended conditions. Sr and Mn results from these methods and the previous analyses agreed well for a subset of samples tested to compare the two data sets. Replication of powdered samples had typical standard deviations as follows: $\mathrm{Li} / \mathrm{Ca} 2-208$ (mean of 128); Sr/Ca 2-128; $\mathrm{Mg} / \mathrm{Ca} \mathrm{0.1-48;} \mathrm{Mn} / \mathrm{Ca}$, $2-38$; and $\mathrm{Fe} / \mathrm{Ca}$ generally $<10 \%$. Larger standard deviations for $\mathrm{Li} / \mathrm{Ca}$ were for more heterogeneous samples, i.e., those with higher contents of insoluble residues indicated by visible solids after sample dissolution or with matrix contamination observed in the sampling procedure, and for those with extremely low $\mathrm{Li} / \mathrm{Ca}$ ratios.

Sample treatment methods were checked to ensure that measured $\mathrm{Li} / \mathrm{Ca}$ ratios represented lattice-bound $\mathrm{Li}$. $\mathrm{Li} / \mathrm{Ca}$ ratios in brachiopod shells treated with a sequence of weak acid, oxidative, and reductive steps [Boyle, 1981; Boyle and Keigwin, 1985/86) were the same as $\mathrm{Li} / \mathrm{Ca}$ ratios in untreated replicates. Several powdered samples of whole brachiopod shells of Permo-Carboniferous age (AL5-WB, $T I-83-W B$, and E324-WB) were dissolved in a sequence of acid aliquots. Li/Ca ratios in these sequential partial dissolution aliquots were constant with increasing fraction dissolved, as would be expected for a lattice-bound element; total $\mathrm{Li} / \mathrm{Ca}$ ratios estimated by integrating the dissolution fractions agreed well with those from total dissolutions of matched sample aliquots. Therefore, Li/Ca ratios were determined on untreated samples, with care taken to physically separate samples from contaminating matrix.

\section{RESULTS AND DISCUSSION}

\section{Modern Brachiopods}

$\mathrm{Li} / \mathrm{Ca}$ ratios in the modern brachiopod shells analyzed range from 18 to 50 $\mu$ mol/mol, with one exception (Table 1). 
TABLE 4. Devonian Brachiopods

\begin{tabular}{llllllll}
\hline Sample & $\delta^{13} \mathrm{C}$ & $\delta^{18} \mathrm{O}$ & $\begin{array}{c}\mathrm{LiCa} \\
\mu \mathrm{mol} / \\
\mathrm{mol}\end{array}$ & $\begin{array}{c}\mathrm{Sr} / \mathrm{Ca} \\
\mathrm{mmol} / \\
\mathrm{mol}\end{array}$ & $\begin{array}{c}\mathrm{Mg} / \mathrm{Ca} \\
\mathrm{mmol} / \\
\mathrm{mol}\end{array}$ & $\begin{array}{c}\mathrm{Mn} / \mathrm{Ca} \\
\mu \mathrm{mol} \\
\mathrm{mol}\end{array}$ & $\begin{array}{c}\mathrm{Fe} / \mathrm{Ca} \\
\mathrm{mmol} \\
\mathrm{mol}\end{array}$ \\
\hline Nev-1-a & 1.35 & -4.37 & 25.9 & 1.32 & 3.6 & 346 & 1.59 \\
Dev-2-a & 1.38 & -4.45 & 15.0 & 1.58 & 3.2 & 114 & 0.58 \\
Dev-3-a & 1.50 & -4.26 & 15.2 & 1.58 & 3.3 & 38 & 0.23 \\
Dev-4-a & 1.35 & -4.69 & 22.0 & 1.52 & 3.5 & 331 & 2.34 \\
Dev-5-a & 1.53 & -4.24 & 12.4 & 1.47 & 3.3 & 187 & 0.46 \\
Dev-6-a & 1.50 & -3.98 & 25.8 & 1.57 & 3.5 & 61 & 0.29 \\
Dev-7-a & 1.53 & -4.11 & 25.3 & 1.22 & 2.7 & 50 & 0.29 \\
Dev-8-a & 1.47 & -4.25 & 26.6 & 1.02 & 3.8 & 40 & 0.21 \\
Dev-9-a & 1.74 & -4.07 & 23.2 & 1.14 & 4.6 & 42 & 0.21
\end{tabular}

$\begin{array}{llllllll}\text { Dev-1-c } & 0.63 & -5.28 & (37.3) & 0.44 & 12.7 & 4550 & 26 \\ \text { Dev-2-b } & 0.67 & -4.78 & (34.4) & 0.45 & 13.2 & 4830 & 23 \\ \text { Dev-3-b } & 0.65 & -5.29 & (27.3) & 0.46 & 12.7 & 3960 & 28 \\ \text { Dev-5-c } & 0.56 & -3.97 & 23.0 & 0.27 & 14.0 & 4150 & 12 \\ \text { Dev-8-b } & 0.60 & -5.68 & (57.1) & 0.35 & 17.7 & 3660 & 40 \\ \text { Dev-9-b } & 0.48 & -6.06 & (61.2) & 0.46 & 19.9 & 3850 & 58\end{array}$

\begin{tabular}{llllllll} 
Dev-1-b & -0.44 & -6.99 & 4.9 & 0.12 & 3.1 & 4440 & 10 \\
Dev-5-b & -1.92 & -7.98 & 4.1 & 0.20 & 4.5 & 4580 & 11 \\
Dev-7-b & -1.38 & -6.94 & 3.7 & 0.04 & 2.7 & 3460 & 12 \\
Dev-7-c & -0.93 & -6.99 & 8.2 & 0.04 & 3.2 & 3550 & 10 \\
\hline
\end{tabular}

${ }^{a}$ The brachiopod analyses are all from nonluminescent portions of Mucrospirifer thedfordensis from a single hand sample collected from the Hungry Hollow Formation, Ontario, Canada, of Middle Devonian (Givetian) age. The chemical compositions of these samples are within the ranges observed in modern brachiopods (see Popp et al. [1986b] for details).

${ }^{b}$ Parentheses indicate insoluble residues visible after dissolution.

Li/Ca ratios in samples which include 10 species of modern brachiopods from locations from the Bering Sea to the Caribbean correlate inversely with estimated mean annual temperature at the location and depth of their growth (Figure 1). Estimates of mean annual temperatures and ranges were based on existing oceanographic data on water masses at the same depths from locations as close to collection sites as possible. The $\mathrm{Li} / \mathrm{Ca}$ results group primarily into two subsets that define the apparent temperature dependence, with a $\mathrm{Li} / \mathrm{Ca}$ decrease of -10 $\mu \mathrm{mol} / \mathrm{mol}$ per $10^{\circ} \mathrm{C}$ increase. A sample of Tichosina floridensis from the Dry Tortugas does not correlate with the other samples, with a lower $\mathrm{Li} / \mathrm{Ca}(6 \mu \mathrm{mol} / \mathrm{mol})$ than predicted; it also has lower concentrations of sodium and potassium than the other samples [M.L. Delaney et al., unpublished data, 1989]. There are no

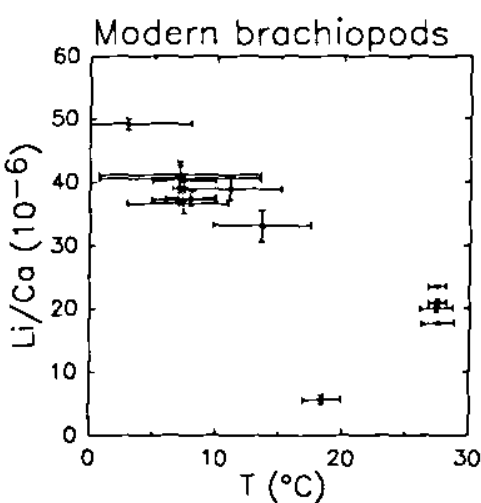

Fig. 1. Li/Ca ratios in modern brachiopod shells versus estimated mean annual in situ temperatures. Vertical error bars represent $\pm 1 \sigma$ on replicate $\mathrm{Li} / \mathrm{Ca}$ analyses; horizontal error bars represent estimated temperature ranges. Linear regression fit is $\mathrm{LI} / \mathrm{Ca}-47.0-0.965 * \mathrm{~T}(\mathrm{n}-15$ excluding CM1) with an $r^{2}$ of 0.9413 . 
TABLE 5. Minor Element and Isotopic Composition of Brachiopod Shells. Means and $2 \sigma / \sqrt{n}$ Standard Deviations

\begin{tabular}{|c|c|c|c|c|c|c|c|}
\hline Time Period & $\delta^{18} \mathrm{O}$ & $\delta^{13} \mathrm{C}$ & $\begin{array}{c}\mathrm{Li} / \mathrm{Ca} \\
\mu \mathrm{mol} / \\
\mathrm{mol}\end{array}$ & $\begin{array}{c}\mathrm{Sr} / \mathrm{Ca} \\
\mathrm{mmol} / \\
\mathrm{mol} \\
\end{array}$ & $\begin{array}{c}\mathrm{Mg} / \mathrm{Ca} \\
\mathrm{mmol} \\
\mathrm{mol}\end{array}$ & $\begin{array}{c}\mathrm{Mn} / \mathrm{Ca} \\
\mu \mathrm{mol} / \\
\mathrm{mol}\end{array}$ & $\begin{array}{c}\mathrm{Fe} / \mathrm{Ca} \\
\mathrm{mmol} \\
\mathrm{mol}\end{array}$ \\
\hline Modern & $\begin{array}{r}0.34 \\
\pm 0.74\end{array}$ & $\sim 2$ & $\begin{array}{r}31.5 \\
\pm 5.5\end{array}$ & $\begin{array}{r}1.45 \\
\pm 0.24\end{array}$ & $\begin{array}{l}12.1 \\
\pm 3.9\end{array}$ & $\begin{array}{r}72 \\
+50\end{array}$ & $\begin{array}{r}0.54 \\
\pm 0.36\end{array}$ \\
\hline Cenozoic & $\begin{array}{r}1.00 \\
\pm 0.66\end{array}$ & $\begin{array}{r}1.87 \\
\pm 0.47\end{array}$ & $\begin{array}{l}30.7 \\
\pm 1.7\end{array}$ & $\begin{array}{r}1.06 \\
\pm 0.05\end{array}$ & $\begin{array}{r}7.1 \\
\pm 2.8\end{array}$ & $\begin{array}{r}36 \\
\pm 21\end{array}$ & $\begin{array}{r}0.44 \\
\pm 0.27\end{array}$ \\
\hline $\begin{array}{l}\text { Permo-Carboniferous } \\
\text { (NL only) }\end{array}$ & $\begin{array}{l}-2.12 \\
\pm 0.81\end{array}$ & $\begin{array}{r}4.88 \\
\pm 1.03\end{array}$ & $\begin{array}{r}5.1 \\
\pm 3.7\end{array}$ & $\begin{array}{r}0.91 \\
\pm 0.36\end{array}$ & $\begin{array}{r}7.1 \\
\pm 5.0\end{array}$ & $\begin{array}{r}43 \\
\pm 14\end{array}$ & $\begin{array}{r}0.19 \\
\pm 0.06\end{array}$ \\
\hline Devonian (NL only) & $\begin{array}{r}-4.27 \\
\pm 0.14\end{array}$ & $\begin{array}{r}1.48 \\
\pm 0.08\end{array}$ & $\begin{array}{r}21.3 \\
\pm 3.7 \\
\end{array}$ & $\begin{array}{r}1.38 \\
\pm 0.14\end{array}$ & $\begin{array}{r}3.5 \\
\pm 0.4 \\
\end{array}$ & $\begin{array}{r}134 \\
\pm 83\end{array}$ & $\begin{array}{r}0.69 \\
\pm 0.51 \\
\end{array}$ \\
\hline
\end{tabular}

apparent intergeneric variations in $\mathrm{Li} / \mathrm{Ca}$ ratios in brachiopods. Different species from similar growth temperatures have similar Li/Ca ratios (Table 1; Figure 1). The average $\mathrm{Li} / \mathrm{Ca}$ ratio for this suite of samples is $-32 \mu \mathrm{mol} / \mathrm{mol}$ (Table 5), corresponding to a mean temperature of $-15^{\circ} \mathrm{C}$. In contrast, foraminiferal $\mathrm{Li} / \mathrm{Ca}$ ratios have no apparent dependence on temperature over the range tested in laboratory culture $\left(20^{\circ}-30^{\circ} \mathrm{C}\right)$ and in sediment trap and core top samples using $\delta^{18} O$ as a temperature proxy [Delaney et al., 1985].

Li incorporation in brachiopod calcite does not appear to vary with $\mathrm{Mg} / \mathrm{Ca}$ ratios in the solids; there is no significant covariance between $\mathrm{Li} / \mathrm{Ca}$ and $\mathrm{Mg} / \mathrm{Ca}\left(x^{2}-\right.$ 0.12 ). Foraminiferal Li/Ca ratios also show no dependence on solution or solid $\mathrm{Mg} / \mathrm{Ca}$ ratios, contrary to the observations of Okumura and Kitano [1986] for inorganic calcite. Sr/Ca and $\mathrm{Mg} / \mathrm{Ca}$ ratios in these brachiopod samples [Lepzelter et al., 1983] show no clear variation with estimated temperatures.

The brachiopod $\mathrm{Li} / \mathrm{Ca}$ ratios are 10-100 times higher than those predicted from experimental studies of alkali incorporation in inorganic calcite; however, these predictions are based on experiments in sodium-, magnesium-, and sulfate-free solutions with $\mathrm{Ca}$ concentrations similar to seawater and $\mathrm{Li}$ concentrations 1000 . 5000 times that of seawater [Okunura and Kitano, 1986]. Brachiopod Li/Ca ratios are about twice those observed in modern foraminifera, which have a mean value of $-15 \pm 3 \mu \mathrm{mol} / \mathrm{mol}$ [Delaney et al., 1985; Delaney and Boyle, 1986]. Physiological processes must play some role in incorporation of $\mathrm{Li}$ in biogenic marine calcites as they do for other trace and minor elements [e.g., Milliman, 1974, p. 14.4; Lorens and Bender, 1977].

\section{Cenozoic Brachiopods}

Li/Ca ratios in nonluminescent brachiopod samples (Pleistocene-Eocene in age) range from $-25-35 \mu \mathrm{mol} / \mathrm{mol}$ (Table 2; Figure 2), with a mean of $31 \pm 2 \mu \mathrm{mol} / \mathrm{mol}$, similar to the modern average (Table 5). Luminescent phases were rarely present; if present, they were filling spaces between brachiopod crystalline fabrics and were

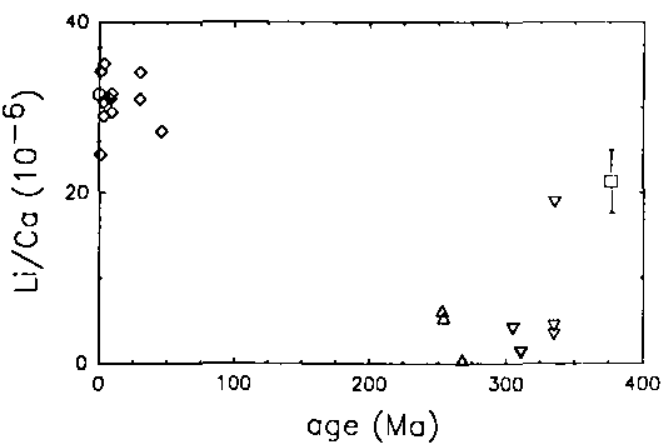

Fig. 2. Li/Ca ratios in nonluminescent brachiopod shells versus age. Li/Ca means $\pm 2 \sigma / \sqrt{ } \mathrm{n}$ standard deviations are shown for modern (circle) and Middle Devonian (square); individual samples are shown for Cenozoic (diamonds), Permian (upright triangles), and Carboniferous (inverted triangles). 
easily avoided during sampling. Sr/Ca and $\mathrm{Mg} / \mathrm{Ca}$ means are slightly lower than modern means, and low $\mathrm{Mn} / \mathrm{Ca}$ and $\mathrm{Fe} / \mathrm{Ca}$ ratios indicate that the samples are well preserved (Table 5). The small range of $\mathrm{Li} / \mathrm{Ca}$ in Cenozoic brachlopods from this linited data set is consistent with the foraminiferal $\mathrm{Li} / \mathrm{Ca}$ record for the Cenozoic [Delaney and Boyle, 1986]. The agreement between two independent $\mathrm{Li} / \mathrm{Ca}$ records thus suggests that we1l-preserved brachiopod shells retain their original Li/Ca ratios at least on the time scale of the Cenozoic.

However, if the $\mathrm{Li} / \mathrm{Ca}$-temperature correlation observed in modern brachiopods is valid for fossil brachiopods, then temperature variations in ancient oceans would have an effect on the $\mathrm{Li} / \mathrm{Ca}$ record of fossil brachiopods. Mean $\delta 180$ for Pleistocene-Miocene samples is +1.1 per mil, and for Oligocene and Eocene samples, +0.8 per mil (Table 2). Paleotemperatures corresponding to these means, calculated assuming seawater $\delta^{18}$ (SMOW) of 0.0 per mil for Pleistocene-Miocene and -0.6 per mil for 01 igocene-Eocene, are $12^{\circ} \mathrm{C}$ and $10^{\circ} \mathrm{C}$, respectively. Using the modern $\mathrm{Li} / \mathrm{Ca}$-temperature linear regression (including uncertainty in temperatures), these predict $\mathrm{Li} / \mathrm{Ca}$ ratios of $32-41$ $\mu \mathrm{mol} / \mathrm{mol}$, in reasonable agreement with the observed means of $-31 \pm 2 \mu \mathrm{mol} / \mathrm{mol}$ for the Cenozoic samples.

\section{Permo-Carboniferous Brachiopods}

Li/Ca ratios are consistently low in the Permo-Carboniferous samples, with the mean approximately one-sixth that of modern and Cenozoic means (Table 3; Table 5 ; Figure 2). These include a number of species and a range of paleotemperatures, over a time interval of nearly $100 \mathrm{~m} . \mathrm{y}$. Other alkali/calcium ratios are also low in these samples. $\mathrm{Sr} / \mathrm{Ca}$ and $\mathrm{Mg} / \mathrm{Ca}$ ratios are similar to those in younger brachiopod samples, and the $1 \mathrm{ow} \mathrm{Mn} / \mathrm{Ca}$ and $\mathrm{Fe} / \mathrm{Ca}$ ratios suggest good preservation. Samples with matrix contamination tended to have extremely high $\mathrm{K} / \mathrm{Ca}$ ratios and $\mathrm{Li} / \mathrm{Ca}$ ratios relative to comparable samples.

Low $\mathrm{L} 1 / \mathrm{Ca}$ ratios in the PermoCarboniferous samples may reflect oceanic composition at the time of deposition, but might have also been controlled by other processes:

1. Permo-Carboniferous brachiopods may have exerted different biological controls over Li incorporation in their shells than modern, Cenozoic, or Devonian ones. If biological control of shell composition changed, it occurred within a superfamily between the Devonian and the Permo-

Carboniferous, as the Devonian samples are from the same superfamily (Spiriferida) as many of the Permo-Carboniferous samples.

2. Brachiopod calcite may have been precipitated at high temperatures. Figure 3 shows mean $\mathrm{Li} / \mathrm{Ca}$ ratios for modern, Permo-Carboniferous, and middle Devonian samples placed within an envelope approximating the modern relationship between $\mathrm{LI} / \mathrm{Ca}$ and temperature. Extrapolating the correlation observed in modern brachlopods to the Permo-Carboniferous data would require temperatures of $40^{\circ}-45^{\circ} \mathrm{C}$ to account for the observed ratios if the oceanic $\mathrm{Li} / \mathrm{Ca}$ ratio for that period was similar to that at present. Such high temperatures are unreasonable, especially for an interval of geologic time marked by epochs of extensive continental glaciation (see review of evidence for extent of glaciation by Hudson and Anderson [1989]). In addition if such high temperatures are assumed, $\delta^{18} 0$ in the ocean would have to have been +2 to +4 per mil to account for the observed $\delta^{18} 0$ values of brachiopod she11s.

3. Permo-Carboniferous brachiopod samples may have been diagenetically

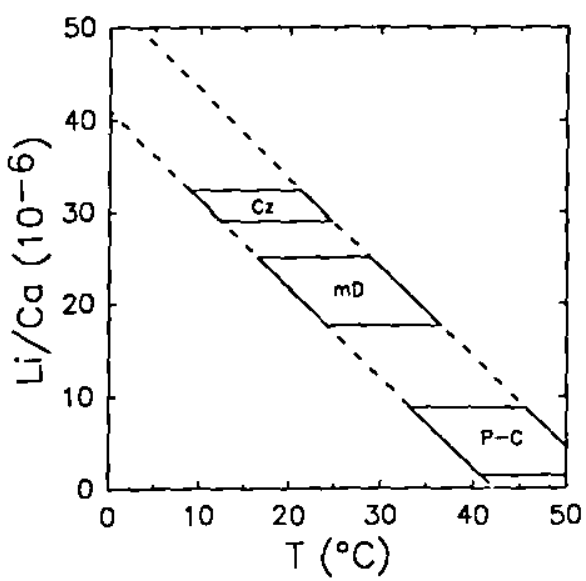

Fig. 3. Li/Ca ratios versus temperature. The dashed lines approximate the range observed for the correlation of $\mathrm{Li} / \mathrm{Ca}$ versus temperature for modern brachiopod shells. Boxes represent $\mathrm{Li} / \mathrm{Ca}$ means $\pm 2 \sigma / \sqrt{ } \mathrm{n}$ standard deviations for nonluminescent portions of Cenozoic $(\mathrm{Cz})$, Permo-Carboniferous (P-C), and middle Devonian (mD) brachiopods placed to fall within the modern trend of $\mathrm{Li} / \mathrm{Ca}$ versus temperature. 
altered. However, this was not apparent in the isotopic or other minor element compositions or in the textural obser. vations. Also, there is relatively good agreement between $\mathrm{Li} / \mathrm{Ca}$ ratios in nonluminescent portions of brachiopods and the equivalent whole brachiopod shells (Table 3), which are expected to display greater effects of alteration [Popp et al., $1986 \mathrm{c}$ ].

These explanations for low $\mathrm{Li} / \mathrm{Ca}$ ratios are unsatisfactory. The most parsimonious explanation is that Permo-Carboniferous brachiopod $\mathrm{Li} / \mathrm{Ca}$ ratios are representative of oceanic composition at the time of deposition. The implications of this explanation are explored in a later section.

Middle Devonian (Givetian) Brachiopods

Li/Ca ratios average $-21 \mu \mathrm{mol} / \mathrm{mol}$ in these samples (Table 4, Figure 2). The $\mathrm{Li} / \mathrm{Ca}$ range is laxger than expected for unaltered samples of one species from the same hand sample. However, there is no obvious trend of $\mathrm{Li} / \mathrm{Ca}$ ratios with other elemental ratios that would suggest diagenetic alteration. $\mathrm{Na} / \mathrm{Ca}$ and $\mathrm{K} / \mathrm{Ca}$ ratios in these samples are similar to those observed in Cenozoic brachiopods [M.L. Delaney et al., unpublished data, 1989]. Micritic matrix samples have $\mathrm{htgh} \mathrm{Li} / \mathrm{Ca}$ and $\mathrm{K} / \mathrm{Ca}$ ratios due probably to leaching of insoluble alumino-silicates during sample dissolution (Table 4). They also have high $\mathrm{Mg} / \mathrm{Ca}$ ratios, presumably also due to leaching; high $\mathrm{Mn} / \mathrm{Ca}$ and $\mathrm{Fe} / \mathrm{Ca}$ ratios and low $\mathrm{Sr} / \mathrm{Ca}$ ratios are attributed to diagenetic recrystallization. The sparry cements, with low $\delta^{18} \mathrm{O}$ and $\delta^{13} \mathrm{C}$ values relative to brachiopods, have lower $\mathrm{Li} / \mathrm{Ca}, \mathrm{Na} / \mathrm{Ca}, \mathrm{K} / \mathrm{Ca}$, and $\mathrm{Sr} / \mathrm{Ca}$ ratios than the nonluminescent brachiopod shells.

For the middle Devonian nonluminescent brachiopods, in contrast to the PermoCarboniferous samples, slightly higher marine temperatures can account for the lower observed $\mathrm{Li} / \mathrm{Ca}$ ratios without requiring lower oceanic Li/Ca than today's value (Figure 3).

\section{IMPLICATIONS FOR THE PALEOZOIC GEOCHEMICAL} CYCLE OF LITHIUM

The two important $\mathrm{Li}$ sources to the ocean are high-temperature hydrothermal circulation $\left(F_{h}\right)$ and dissolved river input $\left(F_{\mathrm{r}}\right)$; the two sinks are low-temperature basalt alteration $\left(F_{\ell}\right)$ and sediment uptake
$\left(F_{S}\right)$. The steady state Li concentration in the ocean, $C$, is directly proportional to the sum of the input fluxes and inversely proportional to the removal constants for the two sinks, $k_{\ell}$ and $k_{s}$, assuming first-order removal constants (i.e., that removal in the low-temperature basalt alteration sink is $\mathrm{k}_{\ell} \mathrm{C}$ and similarly for removal in the sedimentary sink) [Delaney and Boyle, 1986].

$$
c=\frac{F_{h}+F_{r}}{k_{\ell}+k_{s}}
$$

Thus, changes in hydrothermal or weathering fluxes must be considered to explain observed variations in steady state $\mathrm{Li}$ concentrations.

High-temperature basalt alteration, a Li source, increases $\delta^{18} 0$ of the hydrosphere, whereas low-temperature basalt alteration, an important Li sink, decreases $\delta^{18} 0$, as does continental weathering of silicate rocks (see Muehlenbachs and Clayton [1976], Gregory and Taylor [1981],H. Craig (reported by Holland [1984], p. 246), and Bowers [1988]). However, the response time for $\delta 180$ in the ocean is much longer ( $-50 \mathrm{m.y.}$ ) than the $\mathrm{Li}$ residence time [Muehlenbachs and Clayton, 1976; Gregory and Taylor, 1981; Edmond et a1., 1979; Stoffyn-Egli and Mackenzie, 1984]. If changes in high-and low-temperature alteration dominate both steady state mass balances, $\mathrm{Li}$ and $18_{0}$ (as $\delta^{18_{0}}$ of seawater) should parallel each other at least qualitatively, with higher Li concentrations and more positive $\delta^{18} 0$ coupled.

Nonluminescent portions of brachiopods, whole brachiopod shells (and other whole fossils), and marine cements all have relatively low $\delta^{18}$ o values around -4 per mil in samples of Devonian age and older. The $\delta^{18} 0$ record of these marine carbonates shows a positive shift of $2-3$ per mil in the Early Carboniferous to values compatible with an oceanic $\delta^{18} 0$ similar to that for the Cenozoic preglacial ocean [Given and Lohmann, 1985; Meyers and Lohmann, 1985; Popp et a1., 1986c; Veizer et a1., 1986; Hudson and Anderson, 1989].

For Permo-Carboniferous brachiopods, ${ }^{18} 0$ values similar to those of the Cenozoic constrain both high- and lowtemperature hydrothermal basalt alteration fluxes and weathering fluxes to be similar to present ratios of these fluxes. Low Permo-Carboniferous $\mathrm{Li} / \mathrm{Ca}$ ratios $(<20 \%$ of present, -25 of Devonian) could reflect 
either a lower river flux contribution of Li or greater $\mathrm{Li}$ burial with sediments. The mechanism of $\mathrm{Li}$ enrichment in sediments is not known, but may involve formation of authigenic minerals [Stoffyn-Egli and Mackenzie, 1984]. Li burial fluxes in calcite and opal sedimentation are minor, each $<28$ of total removal [Delaney, 1983]. Li/Al ratios are similar in marine shales and clays, silts and sands, and carbonates, but are higher than that in igneous rock precursors [Holland, 1984]. Therefore, $\mathrm{Li}$ removal by sediments is probably proportional to aluminosilicate burial.

Lower oceanic $\mathrm{Li} / \mathrm{Ca}$ ratios with a hydrosphere $\delta^{18} 0$ similar to the modern value could result from (1) lower rates of chemical weathering, or (2) higher rates of clastic sedimentation, or (3) more efficient Li enrichment in sediments. If lower $\mathrm{L} 1 / \mathrm{Ca}$ ratios are due to lower rates of chemical weathering on the continents and a reduced dissolved Li flux from silicate weathering, more positive $\delta^{18} 0$ would be expected. However, the effect of decreased chemical weathering on the oxygen isotope balance depends on rock types weathered. Weathering of sediments has 1ittle effect on the $\delta^{18} 0$ balance of the hydrosphere because the eventual products have the same $\delta 180$ as the reactants. Thus, steady state $\delta^{18} 0$ would be little affected if the rates of sediment weathering and hence the Li supply from sediment weathering to the ocean diminished.

If lower $\mathrm{Li} / \mathrm{Ca}$ ratios are due to more efficient sediment uptake of $\mathrm{Li}$ at constant rates of clastic sediment deposition, then this should be reflected in greater Li enrichment in shales of that age (1.e., higher $\mathrm{LI} / \mathrm{Ca}$ ratios). There is no evidence for this in the Permo-

Carboniferous shales from the Russian Platform data set of A.B. Ronov et al. (1970) (as reported by Holland [1984], pp. $212-221$ ). However, a greater Li flux to the sediments could also be due to greater erosion rates and a higher rate of clastic sedimentation at a constant degree of $\mathrm{Li}$ enrichment. Larger mechanical weathering rates or more extensive sediment $\mathrm{Li}$ enrichment also would not affect $\delta^{18}$.

For the middle Devonian samples, more negative $\delta^{18} \mathrm{O}$ and lower $\mathrm{Li} / \mathrm{Ca}$ ratios than at present could both reflect a reduced importance of high-temperature basalt alteration in both mass balances. This effect and higher growth temperatures may both have acted to produce the Devonian brachiopod signals.

\section{CONCLUSIONS}

Li/Ca ratios in a suite of modern brachiopod shells generally correlate with growth temperature, with values ranging from $-20 \mu \mathrm{mol} / \mathrm{mol}$ at $30^{\circ} \mathrm{C}$ to $\sim 50 \mu \mathrm{mol} / \mathrm{mol}$ at $0^{\circ} \mathrm{C}$. Causes of this temperature effect are not clear and warrant further investigation. Li/Ca ratios from a limited survey of Cenozoic brachiopods support observations about the relative constancy of oceanic $\mathrm{Li} / \mathrm{Ca}$ from foraminiferal records [Delaney and Boyle, 1986] and the preservation of the Li/Ca signal in brachiopod calcite over geologic time spans.

Comparisons of $\mathrm{Li} / \mathrm{Ca}$ ratios for nonluminescent portions of brachiopod shells and for paired matrix samples with larger amounts of insoluble residue indicate that Li concentrations from bulk carbonate rock analyses may be greater than low-magnesium calcite Li contents. Li concentrations from a compilation of Li contents of Phanerozoic carbonate sedimentary rocks average about $15 \mathrm{ppm}$ [Holland, 1984], equivalent to a $\mathrm{Li} / \mathrm{Ca}$ mole ratio of over $200 \mu \mathrm{mol} / \mathrm{mol}$. This ratio is 6 times the mean values for modern and Cenozoic brachiopod shells carefully separated from any matrix contaminants. These elevated Li concentrations from whole carbonate rocks probably result from leaching of $\mathrm{Li}$ from noncarbonate fractions during sample dissolution in the laboratory. Caution must be used in interpreting bulk rock $\mathrm{Li}$ analyses as records of oceanic $\mathrm{Li}$ concentrations.

$\mathrm{Li} / \mathrm{Ca}$ ratios for the nonluminescent portions of Permo-Carboniferous brachiopods are strikingly low, less than 208 of present values. Explanations for these low ratios based on diagenetic alteration are inconsistent with textural observations and other minor element ratios indicating these shells are unaltered. If the low $\mathrm{Li} / \mathrm{Ca}$ ratios are reasonably accurate monitors of seawater chemistry, they strongly suggest important changes during the Paleozoic in the sedimentary fluxes of Li and/or in continental weathering rates. Large changes in the Permo-Carboniferous of fluxes involving the oceanic crust are less likely because these should lead to changes in $\delta^{18} 0$ of seawater that are not consistent with the observed $\delta^{18} 0$ record of marine carbonates.

$\mathrm{Li} / \mathrm{Ca}$ ratios in Devonfan brachlopods are about 70 of of those in modern brachi. opods. Two explanations are consistent with this observation: (1) somewhat 
higher temperatures for brachiopod growth, provided that the correlation of $\mathrm{Li} / \mathrm{Ca}$ with temperature in modern brachiopods is applicable to Devonian brachiopods, and/or (2) somewhat lower oceanic Li/Ca ratios, consistent with the argument that more negative $\delta^{18} \mathrm{O}$ of seawater during the early and middle Paleozoic is a consequence of a reduced proportion of high-temperature inputs relative to low-temperature basalt alteration.

Future work should focus on defining the nature and causes of the $\mathrm{Li} / \mathrm{Ca}$ temperature correlation, including more data on modern brachlopods and fossil assemblages. Alkali behavior in brachiopod calcite needs more detailed examination, focusing on low $\mathrm{Li} / \mathrm{Ca}$ ratios in Permo-Carboniferous samples. Distinguishing sources of $\mathrm{Li}$ with $\mathrm{Li}$ isotopic analyses, especially for the PermoCarboniferous brachiopods, may define what changes occurred. Stratigraphic gaps in this brachiopod $\mathrm{Li} / \mathrm{Ca}$ record, both in the Paleozoic and in younger sections, need to be filled.

Acknowledgments. We are grateful to Richard Grant, Museum of Natural History, Smithsonian Institution, and to the staff at the American Museum of Natural History for allowing us to obtain brachiopod samples for analyses. M.L.D. acknowledges funding from UCSC seed money sources for partial support of this work and a UCSC pretenure award for course relief to allow time for this research. B.N.P. thanks J.L. Reichelderfer for assistance during sample selection. We thank J.M. Hayes for allowing access to the Biogeochemical Laboratories at Indiana University and S.A. Studley for assistance with laboratory preparations. We thank Samuel Savin and Bruce Wilkinson for their helpful comments and suggestions, which resulted in a much improved manuscript.

\section{REFERENCES}

Bowers, T. S., Stable isotope signatures of water-rock interactions in mid-ocean ridge hydrothermal systems, Geol. Soc. Am. Abstr. Programs, 20, A96, 1988 .

Boyle, E. A., Cadmium, zinc, copper, and barium in foraminifera tests, Earth Planet. Sci. Lett., 53, 11-35, 1981 .

Boyle, E. A., and L. D. Keigwin, Comparison of Atlantic and Pacific paleochemical records for the last $215,000 \mathrm{y}$ : Changes in deep ocean circulation and chemical inventories, Earth Planet. Sci. Lett, 76, 135-150, $1985 / 86$.

Brand, U., and J. Velzer, Chemical diagenesis of a multicomponent carbonate system, 1, Trace elements, J. Sediment. Petrol, 50, 1219-1236, 1980.

Chan, L.-H., and J. M. Edmond, Variation of lithium lsotope composition in the marine environment: A preliminary report, Geochim. Cosmochim. Acta, 52. $1711-1717,1988$.

Delaney, M. L., Foraminiferal trace elements: Uptake, diagenesis, and 100 m.y. paleochemical history, Ph.D. thesis, WHOI-84-2, $253 \mathrm{pp}$. , Mass. Inst. of Technol., Cambridge, 1983.

Delaney, M. L., and E. A. Boyle, Lithium in foraminiferal shells: Implications for high-temperature hydrothermal circulation fluxes and oceanic crustal generation rates, Earth Planet. Sci. Lett, 80, 91-105, 1986.

Delaney, M. L., A. W. H. Bé, and E. A. Boyle, $\mathrm{Li}, \mathrm{Sr}, \mathrm{Mg}$, and $\mathrm{Na}$ in foraminiferal calcite shells from laboratory culture, sediment traps, and sediment cores, Genchim. Cnsmochim. Acta, 49, 1327-1341, 1985.

Edmond, J. M., C. Measures, R. E. McDuff, L. H. Chan, R. Collier, B. Grant, L. I . Gordon, and J. B. Corliss, Ridge crest hydrothermal activity and the balances of the major and minor elements in the ocean: The Galapagos data, Earth Planet. Sci. Lett. $46,1-18,1979$

Given, R. K., and K. C. Lohmann, Derivation of the original isotopic composition of Permian marine cements, J. Sediment. Petrol, 55, 430-439, 1985 .

Gregory, R. T., and H. P. Taylor, Jr., An oxygen isotope profile in a section of Cretaceous oceanic crust, Samail ophiolite, Oman: Evidence for $\delta^{18_{0}}$ buffering of the oceans by deep $(>5 \mathrm{~km})$ seawater-hydrothermal circulation at mid-ocean ridges, J. Geophys. Res., $\underline{86}$, 2737-2755, 1981.

Holland, H. D., The Chemistry of the Atomosphere and Oceans, $351 \mathrm{pp}$., John Wiley, New York, 1978.

Holland, H. D., The Chemical Evolution of the Atmosphere and Oceans, $582 \mathrm{pp}$., Princeton University Press, Princeton, N.J., 1984.

Hudson, J.D., and T.F. Anderson, Ocean temperatures and isotopic compositions through time, Proc. R. Soc, Edinburgh, in press, 1989 .

Lepzelter, C. G., T. F. Anderson, and P. A. Sandberg, Stable isotope variation in 
modern articulate brachiopods (abstract) Am. Assoc. Pet, Geol. Bul1, 67, 500501,1983 .

Lorens, R.B., and M.L. Bender, Physiological exclusion of magnesium from Mytilus edulis calcite, Nature, 269, 793-794, 1977.

Lowenstam, H. A., Mineralogy, $0^{18} / 0^{16}$ ratios, and strontium and magnesium contents of recent and fossil brachiopods and their bearing on the history of the oceans, J. Geol. 69, $241-260,1961$.

Meyers, W. J., and K. C. Lohmann, Isotope geochemistry of regionally extensive calcite cement zones and marine components in Mississippian limestones, New Mexico, in Carbonate Cements, Spec. Pub1. 36, edited by N. Schneidermann and P. M. Harris, pp. 233-240, Society of Economic Paleontologists and Mineralogists, Tulsa, Okla., 1985.

Milliman, J.D. Marine Carbonates, 375 pp., Springer-Verlag, New York, 1974.

Muehlenbachs, K., and R. N. Clayton, oxygen isotope composition of the oceanic crust and its bearing on seawater, I. Geophys. Res., 81, 4365 $4369,1976$.

Okumura, $\mathrm{M}$, and $\mathrm{Y}$., Kitano, Coprecipitation of alkali metal ions with calcium carbonate, Geochim. Cosmochim. Acta, 50, 49-58, 1986.

Popp, B. N., F. A. Podosek, J. C. Brannon, $T$. F. Anderson, and $J$. Pier, ${ }^{87} \mathrm{Sr} /{ }^{86} \mathrm{Sr}$ ratios in Permo-Carboniferous sea water from the analyses of well-preserved brachiopod shells, Geochim. Cosmochim. Acta, 50, 1321-1328, 1986a.

Popp, B. N., T. F. Anderson, and P. A. Sandberg, Textural, elementa1, and isotopic variations among constituents in Middle Devonian 1imestones, North America, $\underline{\mathrm{J}}$. Sediment, Petrol, 56,715 $727,1986 \mathrm{~b}$.

Popp, B. N., T. F. Anderson, and P. A. Sandberg, Brachiopods as indicators of original isotopic compositions in some Paleozolc limestones, Geol, Soc. Am. Bul1, 97, 1262-1269, 1986c.

Stoffyn-Egli, P., and F. T. Mackenzie, Mass balance of dissolved lithium in the oceans, Geochim, Cosmochim. Acta, 48, 859-872, 1984.

Veizer, J., P. Fritz, and B. Jones, Geochemistry of brachiopods: Oxygen and carbon isotopic records of Paleozoic oceans, Geochim. Cosmochim. Acta, 50, $1679-1696,1986$.

Von Damm, K. L., J. M. Edmond, B. Grant, C. I. Measures, B. Walden, and R. F. Weiss, Chemistry of submarine solutions at $21{ }^{\circ} \mathrm{N}$ East Paciflc Rise, Geochim. Cosmochim, Acta, 49, 2197-2220, 1985 .

T. F. Anderson and C. G. Lepzelter, Department of Geology, University of Illinois, Urbana, IL 61801.

M. L. Delaney, Institute of Marine Sciences, University of California, Santa Cruz, CA 95064.

B. N. Popp, Biogeochemical Laboratories, Departments of Chemistry and Geology, Indiana University, Bloomington, IN 47405 .

(Received May 16, 1989; revised August 10, 1989; accepted August 11, 1989.) 